Scientia Marina 71(2)

June 2007, 269-277, Barcelona (Spain)

ISSN: 0214-8358

\title{
Lipid reserves of red mullet (Mullus barbatus) during pre-spawning in the northwestern Mediterranean
}

\author{
JOSEP LLORET ${ }^{1}$, MONTSERRAT DEMESTRE $^{2}$ and JOSEP SÁNCHEZ-PARDO ${ }^{2}$ \\ ${ }^{1}$ University of Girona, Faculty of Sciences, Dept. of Environmental Sciences, Campus Montilivi, E-17071 Girona, \\ Catalonia, Spain. E-mail: josep.1loret@udg.edu \\ ${ }^{2}$ Institut de Ciències del Mar (CSIC), Pg. Marítim 37-49, E-08003 Barcelona, Catalonia, Spain.
}

\begin{abstract}
SUMMARY: Lipid reserves are a particularly important attribute of fishes because they have a large influence on growth, reproduction and survival. This study analyses the lipid content of red mullet (Mullus barbatus) pre-spawners in three different areas of the northwestern Mediterranean in relation to trawling activities and river runoff. The muscle lipid was considered as an indicator of the somatic condition of individuals whilst the gonad lipid was used as a proxy of the energy invested in reproduction. The results show that fish with the highest muscle lipid levels inhabited the area where fishing impact was lowest. Since the abundance and biomass of polychaetes, which represent the main food source for red mullet, were found to be lower in trawled zones than in unfished ones, we suggest that differences in the muscle lipid levels between areas might be attributed to variation in prey abundance in relation to fishing impact. However, no impact of river runoff on lipid reserves of red mullet was observed. The results also show that muscle and gonad lipid reserves are not related to each other during pre-spawning.
\end{abstract}

Keywords: ecological physiology, polychaetes, fishing, river runoff, maerl beds.

RESUMEN: RESERVAS LIPIDICAS DEL SALMONETE DE FANGO (MULLUS BARBATUS) DURANTE LA PREPUESTA EN EL MEDITERRÀNEO NOROCCIDENTAL. - Las reservas lipídicas constituyen un importante atributo de los peces porque juegan un papel destacado en su crecimiento, reproducción y supervivencia. Este estudio analiza las reservas lipídicas del salmonete de fango (Mullus barbatus) durante la prepuesta en tres áreas diferentes del Mediterráneo noroccidental en relación a la actividad pesquera y las descargas fluviales. Se ha considerado el contenido lipídico en el músculo y en la gónada como indicadores de la condición somática y de la energía invertida en la reproducción de los individuos respectivamente. Los resultados muestran cómo los peces con una cantidad mayor de lípidos en el músculo habitan el área donde el impacto pesquero es menor. Puesto que la abundancia y la biomasa de poliquetos, que constituyen la principal fuente de alimento del salmonete de fango, son inferiores en las zonas afectadas por el arrastre que en las zonas donde no se practica este tipo de pesca, se sugiere que las diferencias en la cantidad de lípidos en el músculo entre las distintas áreas podrían atribuirse a las diferencias en la abundancia de presas, lo cual podría guardar relación con la actividad pesquera. Sin embargo, no se observa impacto alguno de las descargas fluviales sobre las reservas de lípidos del salmonete de fango. Los resultados también muestran cómo los contenidos lipídicos en el músculo y en la gónada de los ejemplares no están relacionados entre sí durante la prepuesta de la especie.

Palabras clave: ecofisiología, poliquetos, pesquerías, descargas fluviales, fondos de maerl.

\section{INTRODUCTION}

Lipid reserves are a particularly important attribute of fishes because they have a large influence on growth, reproduction and survival (reviewed by Shulman and Love, 1999), with inadequate reserves being implicated in the reduced reproductive potential of several fish species through reduced fecundity and quality of eggs and larvae or delayed maturation (reviewed by Lambert et al., 2003). Body fat content affects the maturity, spawning and egg quality of many fish species; a deficiency can negatively affect gonad development, fecundity, fertilisation and 
hatching rates (Adams, 1999; Oskarsson et al., 2002). Low energy reserves may also lower the chances of survival of fishes, leading to an increase in natural mortality (Cunjak, 1988; Griffiths and Kirkwood, 1995; Sogard and Olla, 2000). Starvation due to exhaustion of energy reserves, particularly during the non-feeding and reproductive periods, weakens fishes and also renders them more susceptible to predation, diseases and a variety of environmental stressors (Shulman and Love, 1999). Lipids are also known to play a role as regulators of body density, buoyancy, cellular metabolism, detoxification and behaviour (Adams, 1999; Morris and Culkin, 2000; Clemens and Stevens, 2003). The accumulation of sufficient energy reserves is not only important to safeguard the future population success of harvested species but also to guarantee the viability of other animals feeding on them, including top predators (Wanless et al., 2005).

The fat content of fishes can be affected by habitat characteristics such as bottom or biotope type and food supply, and thus possesses great potential as a 'marker' of habitat quality and feeding conditions in marine (see e.g. Lloret and Planes, 2003; Shulman et al., 2005; Levi et al., 2005; Lloret et al., 2002, 2005) and freshwater (see e.g. Clemens and Stevens, 2003; Pothoven et al., 2006) ecosystems. However, fish lipid reserves have seldom been used to assess fishing impacts on fish species and most research has dealt with changes of abundance, biomass, growth and maturity of individuals in relation to harvesting.

Red mullet (Mullus barbatus L., 1758) is a common demersal fish species that inhabits the soft bottoms of the continental shelf of the Mediterranean and the northeast Atlantic (Hureau, 1986). It serves as food to a number of fishes such as hake (Carpentieri et al., 2005) and bonito (Yoshida, 1980), and is a major target species of Mediterranean demersal fisheries because of its high abundance and economic value (Demestre et al., 1997; Relini et al., 1999; Tserpes et al., 2002). Its high abundance, narrow spawning season and wide spatial distribution make it a suitable species for testing habitat and fishing effects on fish energy reserves.

The aim of the present study is to analyse, from an ecophysiological perspective, the lipid reserves of red mullet in different areas of the northwestern Mediterranean, showing differences in fishing impact and freshwater runoff. Higher diversity and abundance of benthic organisms can be found in the seabed zones less impacted by trawling activities (Kaiser et al., 1999; Demestre et al., 2000a; Eleftheriou, 2000; Smith et al., 2000; Sánchez et al., 2000). Furthermore, freshwater inflow is known to enhance benthic productivity in coastal areas (Montagna and Yoon, 1991; Montagna and Kalke, 1992; Salen-Picard et al., 1997; Massé, 2000). In the northwestern Mediterranean, a positive response of benthic populations - particularly polychaetes - to river runoff has been shown (Salen-Picard et al., 1997; Massé, 2000). As polychaetes represent the main food supply for red mullet (Labropoulou and Eleftheriou, 1996; Machias and Labropoulou, 2002), we hypothesise that differences in abundance and biomass of these benthic animals, linked to fishing impact and river runoff, may determine in part the lipid reserves of fish in each study area. The study is conducted during pre-spawning of the species - a crucial life period for lipid mobilisation and future population success.

\section{MATERIALS AND METHODS}

\section{Fish sample collection}

99 female red mullet pre-spawners, whose lengths ranged between 13 and $22.5 \mathrm{~cm}$, were captured in May-June 2004 during the reproductive period (Bizsel, 1987; FishBase, 2000) on the muddy bottoms of three areas of the Catalan Sea's continental shelf (northwestern Mediterranean): Blanes (33 individuals), Ebre (38 individuals) and Valencia (27 individuals, Fig. 1). Individuals were derived from the MEDITS trawl surveys and from commercial trawlers, and were caught at depths of between 61 and $133 \mathrm{~m}$ (Blanes 61-128 m, Ebre 75$133 \mathrm{~m}$, Valencia 81-131 m). The groundfish surveys followed the technical specifications given in Bertrand et al. (2002).

Individuals were eviscerated, and muscle and gonads were removed. Total length, total weight, eviscerated weight, gonad (ovary) weight and muscle weight were then measured. All females included in the analysis were classified macroscopically to be in the late pre-spawning maturity stage: ovaries were large, with blood capillaries, yellow/orange coloured and with visible but still non-hydrated oocytes. Although initially more than 99 females were collected, some of them were in the early pre-spawning phase (their eggs 


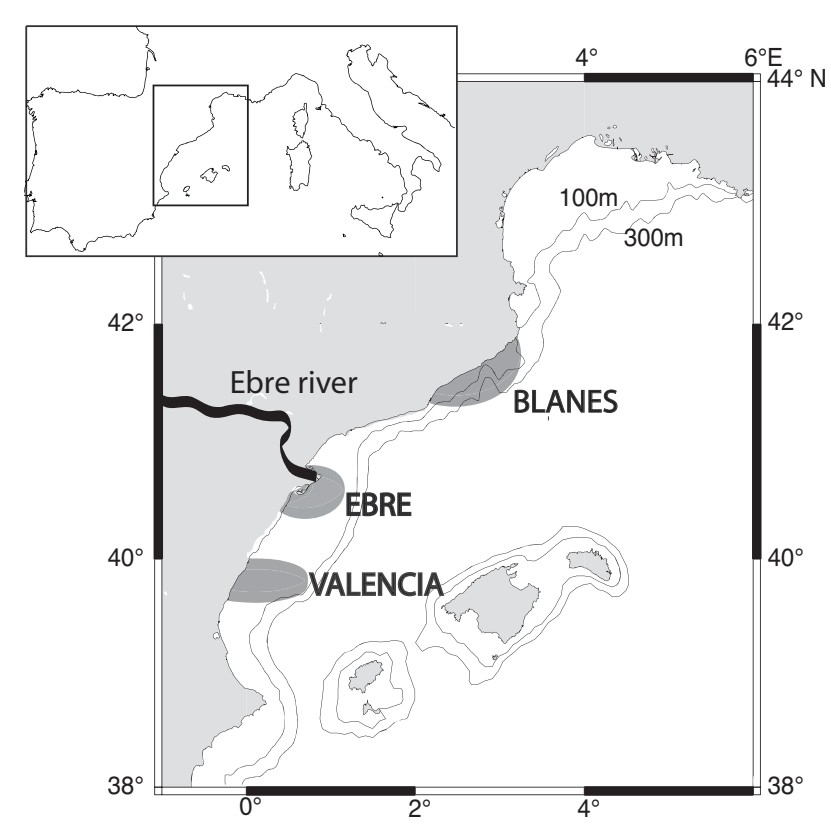

FIG. 1. - Map of the northwestern Mediterranean showing the three study areas: Blanes, Ebre and Valencia.

and ovaries were small) or were already spawning (hydrated eggs), and were therefore disregarded for the analyses. Furthermore, the livers of four individuals were collected and weighed to measure lipid allocation in the various tissues and to help us decide on suitable tissues for analysing fat content. Lengths and wet weights were measured to the nearest $0.5 \mathrm{~cm}$ and $0.01 \mathrm{~g}$, respectively.

\section{Evaluation of total lipids}

Muscle, gonad and liver total lipid content were analysed as a measure of energy reserves during pre-spawning. Determination of total lipid was carried out in these tissues since mesenteric and subcutaneous fat depots were lacking. The whole gonad and liver were taken for lipid analysis, whilst for the muscle a portion of ca $5 \mathrm{~g}$ was taken dorsally directly under the anterior dorsal fin and well above the lateral line. The tissue samples were cleaned of skin, scales and bones, rinsed with seawater and immediately frozen at $-30^{\circ} \mathrm{C}$ for fat content determination in the laboratory.

Samples were unfrozen while deposited on desiccant paper and minced in a Petri dish. To determine dry muscle and gonad weights, samples were desiccated first at $70^{\circ} \mathrm{C}$ for 24 hours in a stove and second under vacuum for 12 hours. The dry samples were put in a mortar together with anhydrous sodium sulphate previously desiccated in a stove at $100^{\circ} \mathrm{C}$ for 24 hours. Tissue samples and sodium sulphate were then vigorously ground to a fine powder. The anhydrous sodium sulphate contributes to the complete desiccation of samples and avoids the formation of tissue aggregates, thus improving the grinding process (samples become better homogenised) and optimising the lipid extraction afterwards.

Total lipids were determined gravimetrically with the Soxhlet method according to Shahidi (2001). The Soxhlet is a commonly used semi-continuous method applied to extraction of lipids from fishes (see e.g. Belk, 1993; Tornaritis et al., 1993; Clemens and Stevens, 2003; Pothoven et al., 2006). Lipids were extracted by repeated washing (percolation) with a volume of $200 \mathrm{ml}$ of hexane/acetone $(1: 1 \mathrm{v} / \mathrm{v})$ for ca. $0.5-1.0 \mathrm{~g}$ of sample. This organic solvent mixture flowed for several cycles through the sample into a glass vitrified capsule (thimble) by distillation using heating mantles. By using pure (100\% lipid) cod liver oil, adsorbed in a similar matrix, this gravimetric method was able to extract as much of $99.22 \%$ of total lipids.

The ground samples were placed in the porous thimbles of the Soxhlet apparatus together with a number of little glass balls (boiling chips) to avoid splash projections during extraction. The extraction time was between 5 and 8 hours depending on sample aggregation and taking into account that the distillation rate must be about 2 to 6 drops per second. When the extraction-measured with an internal standard in a similar matrix - was complete, the content of the flask was filtrated and evaporated using a rotary evaporator and weighed in a previously calibrated flask. The lipid content in the samples was then calculated by differences in weight. After the gravimetric determination of the total lipid content in the sample with a balance (to the nearest $0.1 \mathrm{mg}$ ), values were corrected for a recovery ratio of $99.22 \%$.

The lipid compartmentalisation was studied by analysing the relative and absolute lipid content in the muscle, gonad and liver of four individuals. In these female pre-spawners, lipids constituted between 15.042 and $18.773 \%$ of the dry liver, between 4.656 and $9.197 \%$ of the dry muscle and between 15.403 and $27.078 \%$ of the dry gonad. On the other hand, the absolute fat content in the livers ranged between 0.04 and $0.06 \mathrm{~g}$ between 0.38 and $0.89 \mathrm{~g}$ in the muscles and between 0.26 and $0.63 \mathrm{~g}$ in the gonads. Thus, although the percent- 
age of fat in the liver was relatively high, the absolute amount of lipid stored in this organ was small compared to that stored in the gonad and the muscle. Because of this, we assumed that muscle constitutes the major source of lipid reserves in red mullet, so we analysed only the total lipid content (\% dry weight) in the muscle and the gonad of the rest of the female pre-spawners.

The relative muscle and gonad lipid contents, expressed as a percentage of dry masses, were given, and a Lipid Musculosomatic index (LMSI) and a Lipid Gonadosomatic index (LGSI) were computed with the formulas

$$
\begin{aligned}
\text { LMSI } & =\left[\frac{A B S M}{E W} \times 100\right] \text { and } \\
\text { LGSI } & =\left[\frac{A B S G}{E W} \times 100\right],
\end{aligned}
$$

where EW is the eviscerated wet weight and ABSM and ABSG are the absolute lipid content in the muscle and gonad, respectively, computed by multiplying the respective lipid contents (in \% wet weight) by total muscle and gonad wet weights. The relative muscle lipid content and the LMSI were considered as indicators of red mullet condition, whilst the relative lipid content in the gonad and the LGSI were used as proxies of the energy reserves invested in reproduction.

\section{Food supply, fishing impact and river runoff}

Since the condition of a fish is a measure of physical and biological circumstances during some previous period (Shulman and Love, 1999), available historic data on red mullet's food supply, fishing impact and river runoff were gathered. To evaluate a possible effect of trawling on red mullet's food supply, the abundance and biomass of polychaetes, which are the dominant prey of red mullet (forming ca. $60 \%$ by number and $50 \%$ by weight of its diet followed by small decapods and amphipods, Labropoulou and Eleftheriou, 1996; Aguirre, 2000; Machias and Labropoulou, 2002), were computed during 2002-2004 in a fished and an unfished zone within the Ebre area, where the soft-bottom communities are dominated by polychaetes (Demestre, 2006) and where the fishing impact is higher than in the other study areas. During the period 1989-2004, the Ebre area was affected by the highest values of number of trawlers (198), total capacity (7083 gross registered tonnage, GRT), total machine power (48425 HP) and fishing days per year (43560), according to the Official Census of Fishing Vessels of the Spanish Ministry of Agriculture and Fisheries, whilst the lowest values were recorded in Valencia (49 trawlers, 2155 GRT, 12675 HP and 10780 fishing days per year, Table 1). These values are means over the whole period (1989-2004). Days at sea per year were estimated assuming that each vessel fishes 5 days a week and 11 months a year. Data from a given area considered the trawling fleet based in all fishing ports from that area. Since trawlers are obliged by law to make one-day trips (i.e. they depart early in the morning and return late in the afternoon), fishing takes place within a short distance (ca. 5-10 miles) from the port. Thus, the fleet from a given port tend to operate in the fishing grounds nearby. Benthic fauna (including polychaetes) were sampled during seven surveys (November 2002, June, July, August, September and November 2003, and June 2004) in the framework of the EU RESPONSE project (contract no. Q5RS2002-00787). During each survey, polychaetes were sampled from five stations in the fished and adjacent unfished zones, which were both comprised between 47 and $61 \mathrm{~m}$ depth on muddy bottoms. Five replicate samples were collected with a $0.1 \mathrm{~m}^{2}$ van Veen grab from each station. Samples were sieved through a $1 \mathrm{~mm}$ sieve on board and preserved in 5\% buffered formalin. For each sample, the total number of polychaetes and their biomass (in $\mathrm{g}$ wet weight) per square metre were calculated

The freshwater discharged in each area was calculated by integrating the runoff (in cubic hectometres; $\mathrm{Hm}^{3}$ ) of the most important rivers flowing into each area, from January 1970 to June 2004: the Rivers Tordera and Besós in the Blanes area (data gathered from the Agencia Catalana de l'Aigua Dept. of Environment of the Autonomous Government of Catalonia), the River Ebre in the Ebre area (data gathered from the Confederación Hidrográfica del Ebro - Spanish Ministry of

TABLE 1. - Statistics for the trawler fleet in each study area (data are means over the period 1989-2004).

\begin{tabular}{lcccc} 
Area & $\begin{array}{c}\text { Total number } \\
\text { of trawlers }\end{array}$ & $\begin{array}{c}\text { Total capacity } \\
\text { (grossregistered } \\
\text { tonnage, GRT) }\end{array}$ & $\begin{array}{c}\text { Total machine } \\
\text { power (HP) }\end{array}$ & $\begin{array}{c}\text { Total days } \\
\text { at sea per } \\
\text { year }\end{array}$ \\
\hline Blanes & 106 & 4645 & 32997 & 23320 \\
Ebre & 198 & 7083 & 48425 & 43560 \\
Valencia & 49 & 2155 & 12675 & 10780 \\
\hline
\end{tabular}




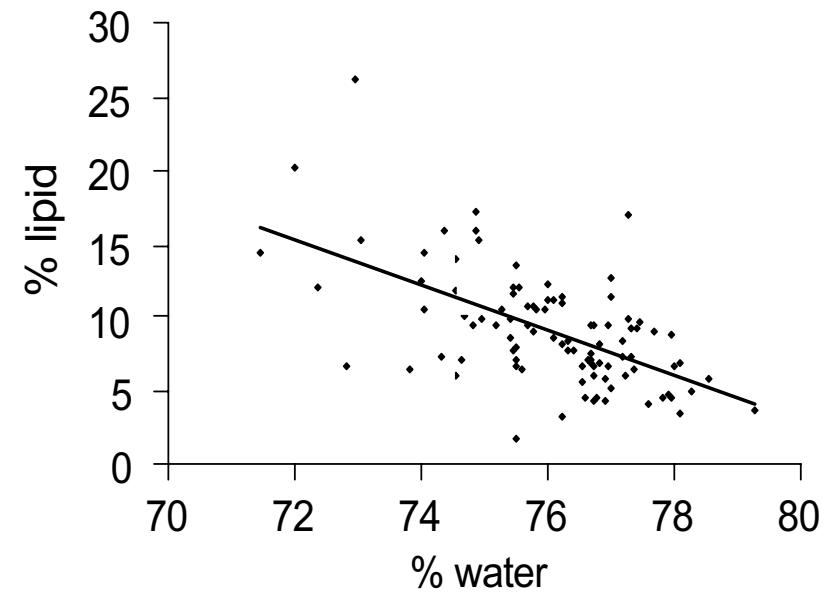

FIG. 2. - Linear relationship between the lipid content ( $\%$ dry weight) and the water content in the muscle. $y=-1.553 \mathrm{x}+127.14$, $\mathrm{r}^{2}=0.34, p<0.05, \mathrm{n}=98$.

Environment), and the Rivers Mijares, Palancia and Turia in the Valencia area (data gathered from the Confederación Hidrográfica del Júcar - Spanish Ministry of Environment). Runoff data from the gauging station closest to the sea were always used.

\section{Statistical analyses}

Analyses of variance (ANOVA) and covariance (ANCOVA) models were used to compare lipid content among areas (categorical factors) and depths and lengths (covariates), as well as to ascertain differences in abundance and biomass of polychaetes in the fished and the unfished zone within the Ebre area. Data were ln transformed because the assumptions of normality and homogeneity of variances, tested with Kolmogorov and the Cochran's tests, respectively, were not met. Fisher's post-hoc test (LSD) was used for comparisons of significant effects. For ANCOVA models, the homogeneity of regressions (or slopes) among groups was tested with the test of homogeneity of slopes (test of parallelism). A $P$-value $<$ or $=$ to 0.05 was considered statistically significant.

\section{RESULTS}

\section{Lipid reserves}

Lipids constituted between 1.77 and $26.18 \%$ (mean $=9.04 \%, S . E .=0.40, n=98)$ of the dry muscle and between 9.74 and $53.91 \%$ (mean $=25.36 \%$, S.E. $=0.54, n=99$ ) of the dry gonad. The muscle lipid content (as a \% of dry weight) was inversely related to the water content in this tissue (Fig. 2). However, no significant relationship was observed between the relative lipid content in the gonad (\% of dry weight) and the water content.

On the other hand, the relative lipid content in the gonad decreased with fish length (linear regression, \% lipid in the gonad $=-1.02 * \mathrm{TL}+43.52$, $\mathrm{p}<0.05, \mathrm{n}=99$ ), even though the coefficient of determination was low $\left(r^{2}=0.19\right)$, whilst the percentage of fat in the dry muscle, the LMSI and the LGSI were size-independent within the size ranges of the fish analysed $(p>0.05)$.

The results of the analyses of variance and covariance to test the effect of area on the relative muscle and gonad lipid levels (\% of dry weight), LMSI and LGSI are shown in Table 2. Because the effect of depth was never significant, the analyses were conducted without including this factor. Similarly, length was only included in the analysis of the relative gonad lipid content (in \%), since the effect of fish size on the other parameters analysed was not significant.

TABLE 2. - Summary of results from analyses of variance (ANOVA), covariance (ANCOVA) and post-hoc Fisher test (LSD) evaluating the effect of area (Blanes, Ebre and Valencia) on muscle and gonad lipid content (\% of dry weight), LMSI and LGSI of red mullet; and the effect of zone (fished vs. unfished) on the abundance and biomass of polychaetes in the Ebre area. The symbol $*$ denotes significance at $p<0.05$.

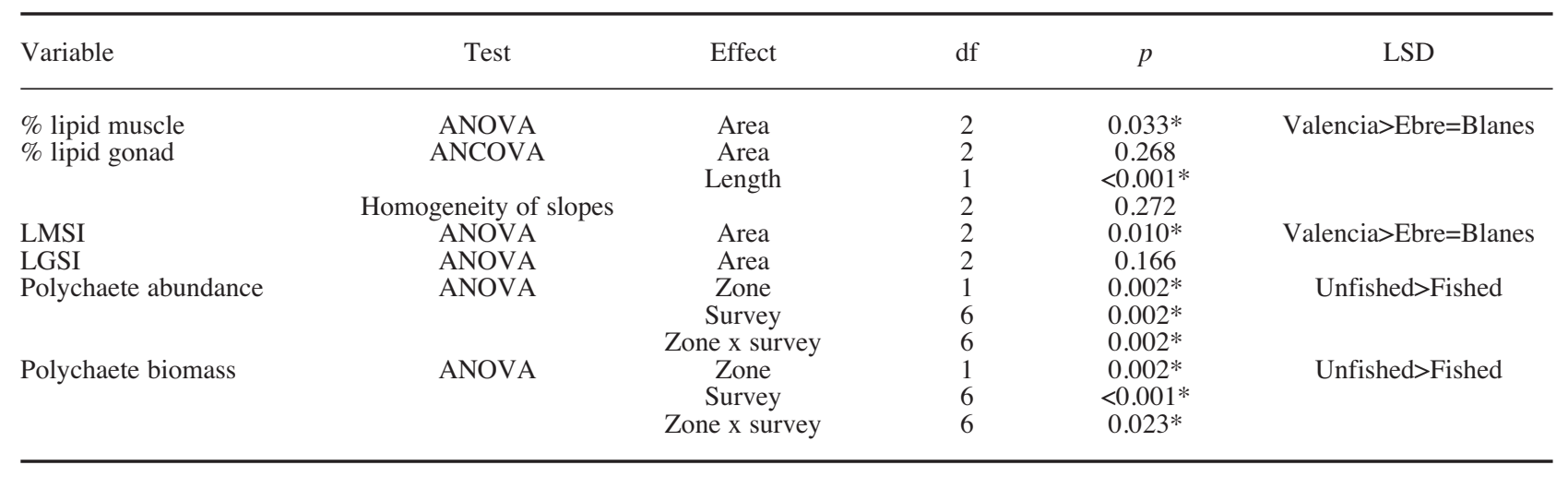




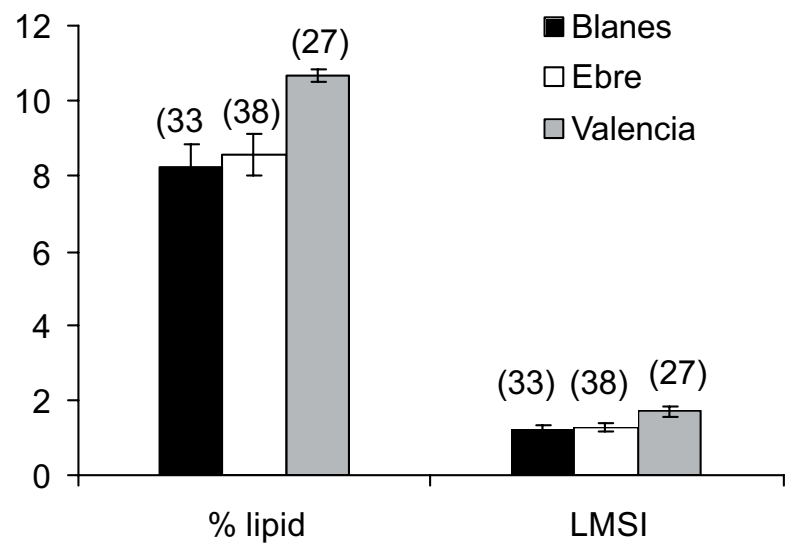

FIG. 3. - Differences in muscle lipid content (\% dry weight, mean +- SE) and Lipid Muculosomatic index (LMSI, mean +-SE) of red mullet female pre-spawners between the study areas (Blanes, Ebre and Valencia). Number of samples are given in brackets.

Individuals from the Valencia area showed a significantly higher percentage of lipid in the muscle than individuals from the Blanes and Ebre areas (Fig. 3). Similarly, the mean LMSI of individuals caught in Valencia was significantly higher than that of individuals caught in the Ebre and Blanes areas (Fig. 3). Thus, red mullet captured in the Valencia area had a higher percentage of fat in the muscle than those collected in the Ebre and Blanes areas. However, statistical analysis did not show significant area variations in gonad fat content (taking into account the effect of length) or LGSI (Table 2).

The percentage of fat in the muscle and the LMSI were not significantly related to the relative gonad lipid content or the LGSI (linear regression, $p>0.05$ ).

\section{Food supply, fishing impact and river runoff}

Comparisons of the abundance and biomass of polychaetes in the fished and unfished zone of the Ebre area in the different benthic surveys showed higher abundance and biomass of polychaetes in the unfished zone than in the fished one, with the exception of the survey conducted in September 2003 (Fig. 4). Considering all benthic surveys together, the abundance of polychaetes ranged between 354 and 1000 individuals per square metre in the unfished zone and between 271 and 850 individuals per square metre in the fished zone. Regarding the biomass, values ranged between 2.26 and $6.03 \mathrm{~g}$ of polychaetes per square metre in the unfished zone and between 1.68 and $4.24 \mathrm{~g}$ per square metre in the fished zone. Results of the analyses of variance showed a significantly higher abundance and biomass of polychaetes in the
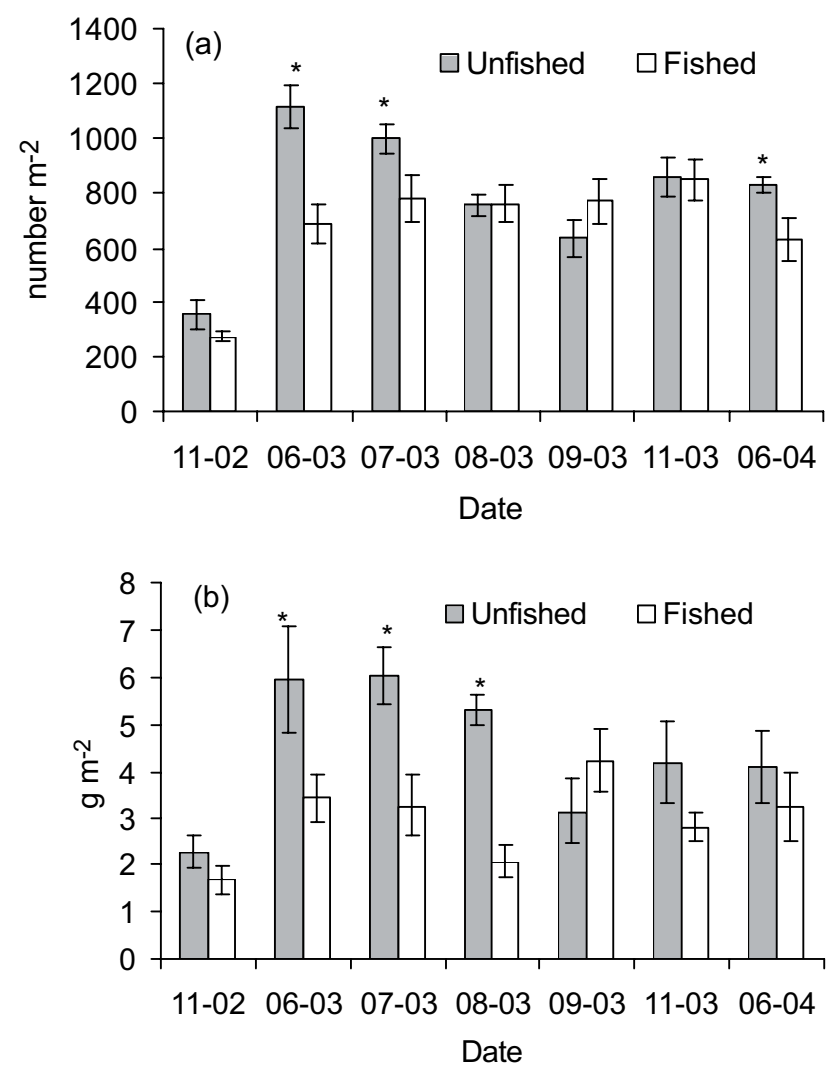

FIG. 4. - Differences in (a) abundance (number $\mathrm{m}^{-2}$, mean +- SE) and (b) biomass $\left(\mathrm{g} \mathrm{m}^{-2}\right.$, mean $\left.+-\mathrm{SE}\right)$ of polychaetes between a fished and an unfished zone within the Ebre area, in the seven benthic surveys: November 2002, June, July, August, September and November 2003, and June 2004. The symbol * denotes that the difference is significant $(\mathrm{p}<0.05$; ANOVA's post-hoc tests; see Table 2).

unfished zone than in the fished one (Table 2). Post-hoc tests of the abundance identified significant treatment (fished vs. unfished) effects on surveys conducted in June and July 2003 and June 2004 (Fig. 4a), whilst post-hoc tests of the biomass provided significant effects on June, July and August 2003 (Fig. 4b).

During the period 1970-2004 (Fig. 5), the Ebre area received between 1784 and $7694 \mathrm{Hm}^{3}$ of annual runoff $\left(\right.$ mean $\left.=4169 \mathrm{Hm}^{3}\right)$, Valencia received between 184 and $1012 \mathrm{Hm}^{3}$ (mean = 488) and Blanes received between 0 and $636 \mathrm{Hm}^{3}$ (mean = 114). The freshwater discharged in all three areas showed a decreasing trend over the whole period (Fig. 5). In June 2004 (when lipid reserves of red mullet were calculated), the total runoff into the Ebre area was $225 \mathrm{Hm}^{3}$, compared to $62 \mathrm{Hm}^{3}$ in the Valencia area and $11 \mathrm{Hm}^{3}$ in the Blanes area. Thus, the Ebre area was the only one to receive large amounts of freshwater runoff whilst the Valencia and Blanes areas received small inputs. 


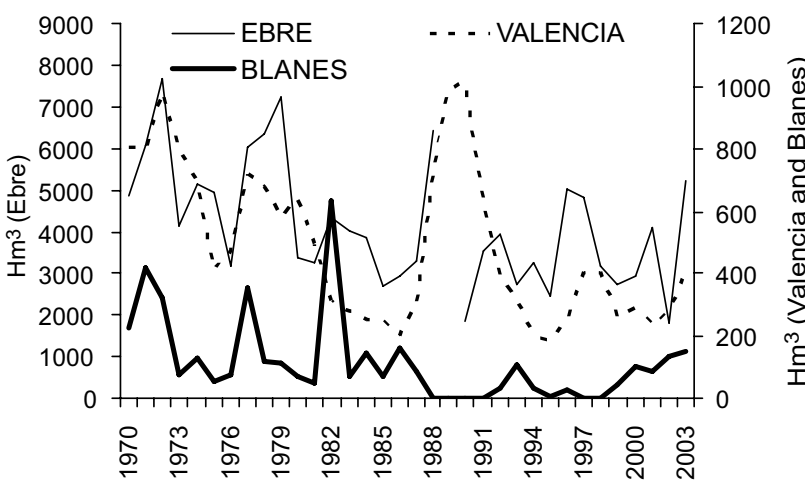

FIG. 5. - Annual freshwater discharged $\left(\mathrm{Hm}^{3}\right)$ into each study area, 1970-2003.

\section{DISCUSSION}

Fish with the highest muscle lipid levels inhabited the area where fishing impact (in terms of number of trawlers, fishing days, total capacity and total machine power) was lowest, i.e. the Valencia area. Furthermore, the abundance and biomass of polychaetes, which represent the main food source for the red mullet (Labropoulou and Eleftheriou, 1996; Machias and Labropoulou, 2002), was lower in trawled zones than in unfished ones. Thus, we suggest that red mullets are fatter in the Valencia area because the lower fishing impact there allows a greater abundance and biomass of polychaetes, as has been demonstrated in the study carried out in the Ebre area. In other Mediterranean areas trawling has been shown to reduce benthic productivity and diversity too (see e.g. Kaiser and De Groot, 2000; Smith et al., 2000). Trawling has also been demonstrated to affect the density of red mullet on muddy bottoms, with higher densities recorded at sites characterised by low fishing activity (Demestre et al., 2000b; Papaconstantinou and Faruguio, 2000; Tserpes et al., 2002), such as the Valencia area (Lombarte et al., 2000).

Apart from the differences in fishing impact between areas, it is important to note the presence of maerl beds in the eastern part of Valencia, where they benefit from the protection of the marine reserve of Columbretes Islands (Templado and Calvo, 2002). Maerl beds are structurally complex and highly productive habitats characterised by accumulations of living and dead unattached calcareous rhodophytes, which provide nursery grounds for demersal marine species (Hall-Spencer and Moore, 2000; BIOMAERL team, 2003). The higher diversity and biomass of benthic animals in these fragile habitats might enhance the red mullet's food supply and explain the higher than average muscle lipid reserves of individuals caught in Valencia. The relative body and liver masses and stomach contents of red mullets caught on maerl beds of the Aegean Sea were found to be higher than those caught on adjacent muddy bottoms (Somarakis et al., 2004). In spite of their ecological importance, maerl beds are under threat from many human activities including trawling (Bordehore et al., 2000; Hall-Spencer and Moore, 2000), particularly in the western Mediterranean (Massutí et al., 1996). Overall, we hypothesise that exploitation might negatively affect the somatic (muscle) lipid reserves of red mullet by reducing the abundance of preys, and that the preservation of sea bottoms against intense trawling activities may be important for the condition of this species.

Even though higher than average red mullet lipid levels in the Ebre area as a consequence of the enhanced benthic productivity in relation to the high freshwater inflow was expected, no significant results were found. It could be hypothesised that the positive effect of Ebre river runoff on polychaete abundance is offset by a negative impact of the high fishing impact existing in that area, or that current densities of polychaetes are relatively low because the Ebre River inflow during recent years has been particularly low compared with the long-term mean.

The results also show that, although red mullet allocates lipid reserves to the gonad during the reproductive period, it does not experience depletion in muscle lipids, which is probably because it feeds intensely at that time (Bizsel, 1987). The match between the reproductive and feeding season may have also led to insignificant relationships between the muscle lipid reserves and the gonad lipid reserves of red mullet, since energy invested in egg production will be obtained directly from feeding instead of the muscle. The negative correlation between the concentrations of water and lipid in the muscle of red mullet is well known for other fish species (Shulman and Love, 1999; Shulman et al., 2005), and water content in the muscle may be thus used in the future as a proxy of lipid content if red mullet condition has to be monitored regularly.

Overall, the results provide evidence that studies on the ecological physiology of wild animals through 
the evaluation of their lipid reserves (particularly if the spatial variation in fat store is accounted for) could be important for population bioenergetics modelling of marine animals such as fishes (Shulman and Love, 1999) and whales (Evans et al., 2003).

\section{ACKNOWLEDGEMENTSS}

This research was funded by a Marie Curie European Reintegration Grant (MERG) of the European Commission and a C-RED Fellowship from the Government of Catalonia (Spain). We thank L. Gil de Sola and the crew of the R/V Cornide de Saavedra for technical and scientific assistance during the MEDITS groundfish surveys, the crew of the R/V García del Cid for assistance during the RESPONSE benthic surveys, S. de Juan and R. Porras for polychaete analyses and I. Clos for lipid analyses in the lab.

\section{REFERENCES}

Adams, S.M. - 1999. Ecological role of lipids in the health and success of fish populations. In: M.T. Arts and B.C. Wainman (eds.), Lipids in freshwater ecosystems, pp. 318-325. SpringerVerlag. New York,

Aguirre, H. - 2000. Aspectos biológicos y ecológicos del salmonete de fango Mullus barbatus L., 1758 y del salmonete de roca Mullus surmuletus L.,1758, del Mediterráneo Noroccidental. $\mathrm{Ph}$. D. thesis, Univ. Politècnica de Catalunya.

Belk, M.C. - 1993. Growth and mortality of juvenile sunfishes (Lepomis sp.) under heavy predation. Ecol.Freshw. Fish., 2: 91-98.

Bertrand, J., L. Gil de Sola, C. Papaconstantinou, G. Relini and A. Souplet. - 2002. The general specifications of the MEDITS surveys. Sci. Mar., 66S2: 9-17.

BIOMAERL team. - 2003. Conservation and management of northeast Atlantic and Mediterranean maerl beds. Aquat. Conserv., 13: S65-S76

Bizsel, K.C. - 1987. Seasonal variations in the diel diet of the red mullets. (Mullus barbatus L.) in the northern Sicilian Basin. Msc. thesis, Institute of Marine Sciences, Middle East Technical University

Bordehore, C., J.A. Borg, E. Lanfranco, A. Ramos-Esplá, M. Rizzo and P. Schembri. - 2000. Trawling as a major threat to Mediterranean maerl beds. Proceedings of the First Mediterranean Symposium on Marine Vegetation (Ajaccio, 3-4 October 2000): 105-109.

Carpentieri, P., F. Colloca, M. Cardinale, A. Belluscio and G.D. Ardizzone. - 2005. Feeding habits of European hake (Merluccius merluccius) in the central Mediterranean Sea.Fish. Bull., 103: 411-416.

Clemens B.J. and E.D. Stevens. - 2003. Buoyancy range, gas bladder volume, and lipid content of adult bloater, Coregonus hoyi Gill, in the Laurentian Great Lakes. Environ. Biol. Fish., 68: 175-182.

Cunjak, R.A., 1988. Physiological consequences of overwintering in streams: the cost of acclimatization? Can. J. Fish. Aquat. Sci., 5: 3-452.

Demestre, M., M. Sobrana, F. Alvarez and P. Sánchez. - 1997. Analysis of the interaction of fishing gear in Mullus barbatus fisheries of the Western Mediterranean. J. App. Icthl., 13: 49-56.

Demestre, M., P. Sánchez and M.J. Kaiser. - 2000a. The behavioural response of benthic scavengers to otter-trawling distur- bance in the Mediterranean. In: M. Kaiser and S.J. De Groot (eds.), Effects of fishing on non-target species and habitats, pp. 121-129. Blackwell Science Publications. London,

Demestre, M., P. Sánchez and P. Abelló. - 2000b. Demersal fish assemblages and habitat characteristics on the continental shelf and upper slope of the north-western Mediterranean. J. Mar. Biol. Ass. U.K., 80: 981-988.

Demestre, M. - 2006. Response of benthic communities and sediment to different regimes of fishing disturbance in European waters (RESPONSE). Final Report. Contract nr. Q5RS2002-00787.

Eleftheriou, A. - 2000. Marine Benthos Dynamics: Environmental and Fisheries Impacts. Introduction and Overview. ICES J. Mar. Sci., 57: 1299-1302.

Evans, K., M.A. Hindell and D. Thiele. - 2003. Body fat and condition in sperm whales, Physeter macrocephalus from southern Australian waters. Comp. Biochem. Physiol. A, 134: 847 -862

FishBase. - 2000. FishBase 2000 CD-ROM. Froese, R., Pauly, D. ICLARM. Manila.

Griffiths, D. and R.C. Kirkwood. - 1995. Seasonal variation in growth, mortality and fat stores of roach and perch in Lough Neagh, Northern Ireland. J. Fish Biol., 47: 537-554.

Hall-Spencer, J.M. and P.G. Moore. - 2000. Scallop dredging has profound, long-term impacts on maerl habitats. ICES J. Mar. Sci., 57: 1407-1415

Hureau, J.C. - 1986. Mullidae. In: P.J.P. Whitehead, M.L. Bauchot, J.C. Hureau, J. Nielsen and E. Tortonese (eds.) Fishes of the northeastern Atlantic and the Mediterranean, pp. 877-882. UNESCO. Paris.

Kaiser, M., S.I. Rogers and J.R. Ellis. - 1999. Importance of benthic habitat complexity for demersal fish assemblages. In: R.L. Benaka (ed.). Essential fish habitat and rehabilitationProc Sea Grant Symposium Fish Habitat, pp. 212-223. American Fisheries Society. Bethesda, U.S

Kaiser, M.J. and S.J. De Groot. - 2000. The effects of trawling on non-target species and habitats: biological, conservation and socio-economic issues. Blackwell Science. Oxford.

Labropoulou, M. and A. Eleftheriou. - 1997. The foraging ecology of two pairs of congeneric demersal fish species: importance of morphological characteristics in prey selection. $J$. Fish Biol., 50: 324-340.

Lambert, Y., N.A. Yaragina, G. Kraus, G. Marteinsdottir and P.J. Wright. - 2003. Using Environmental and Biological Indices as Proxies for Egg and Larval Production of Marine Fish. $J$. Northw. Atl. Fish. Sci., 33: 115-159.

Levi, F. M. Boutoute and P. Mayzaud. - 2005. Lipid Composition of Symphodus ocellatus (Perciforme: Labridae) in the NorthWestern Mediterranean: Influence of Two Different Biotopes. Mar. Biol., 146(4): 805-814.

Lloret, J., L. Gil de Sola, A. Souplet and R. Galzin. - 2002. Largescale habitat variability in condition of demersal fishery species in the north-western Mediterranean. ICES J. Mar. Sci., 59: $1215-1227$

Lloret, J. and S. Planes. - 2003. Condition, feeding and reproductive potential of white seabream (Diplodus sargus) as indicators of habitat quality and the effect of protection in the northwestern Mediterranean. Mar. Ecol. Prog. Ser., 248: 197-208.

Lloret, J., R. Galzin, L. Gil de Sola, A. Souplet and M. Demestre.2005. Habitat related differences in lipid reserves of some exploited fish species in the north-western Mediterranean continental shelf. J. Fish Biol., 67: 51-65.

Lombarte, A., L. Recasens, M. González and L. Gil de Sola. - 2000. Spatial segregation of two species of Mullidae (Mullus surmuletus and M. barbatus) in relation to habitat. Mar. Ecol. Prog. Ser., 206: 239-249.

Machias, A. and M. Labropoulou. - 2002. Intra-specific variation in resource use by red mullet, Mullus barbatus. Est. Coast. Shelf Sci., 55: 565-578

Massé, H. - 2000. Long-term changes in sand-bottom macrofauna along the coast of Provence (northwest Mediterranean Sea). Ocean. Acta 23: 229-242.

Massutí, E., O. Reñones, A. Carbonell and P. Oliver. - 1996. Demersal fish communities exploited on the continental shelf and slope off Majorca (Balearic Islands, NW Mediterranean). Vie Milieu, 46(1): 45-55.

Montagna, P.A. and W.B. Yoon. - 1991. The effect of freshwater inflow on meiofaunal consumption of sediment bacteria and microphytobenthos in San Antonio Bay, Texas. USA. Est. 
Coast. Shelf Sci. 33: 529-547

Montagna, P.A. and R.D. Kalke. - 1992. The effect of freshwater inflow on meiofaunal and macrofaunal populations in the Guadalupe and Nueces estuaries, Texas. Estuaries, 15(3): 307-326.

Morris, R.J. and F. Culkin. - 2000. Fish. In: R.G. Ackman (ed.). Marine biogenic lipids, fats and oils, pp. 67-89. CRC Press. Boca Raton.

Oskarsson, G.J., O.S. Kjesbu, and A. Slotte. - 2002. Predictions of realised fecundity and spawning time in Norwegian springspawning herring (Clupea harengus). J. Sea Res., 48: 59-79.

Papaconstantinou, C. and H. Farrugio. - 2000. Fisheries in the Mediterranean. Medit. Mar. Sci., 1(1): 5-18

Pothoven, S.A. T. Nalepa, C.P Madenjian, R.R Rediske, P J. Schneeberger and J.X. He. - 2006. Energy density of lake whitefish Coregonus clupeaformis in Lakes Huron and Michigan. Environ. Biol. Fish. ,76: 151-158

Relini, G., J. Bertrand and A. Zamboni. - 1999. Synthesis of the knowledge on bottom fishery resources in Central Mediterranean (Italy and Corsica). Biol. Mar. Medit., 6(suppl. 1): 276-299.

Salen-Picard, C., D. Bellan-Santini, G. Bellan, D. Arlhac and R. Marquet. - 1997. Changements à long terme dans une communauté benthique d'un golfe méditerranéen (golfe de Fos). Oceanol. Acta, 20: 299-310.

Sánchez, P., M. Demestre, M. Ramon and M.J. Kaiser. - 2000. The impact of otter trawling on mud communtites in the northwestern Mediterranean. ICES J. Mar. Sci., 57: 1352-1358.

Shahidi, F. - 2001. Extraction and Measurement of Total Lipids. Current Protocols in Food Analytical Chemistry D1.1.1-D1.1.11.

Shulman, G.E. and R.M. Love. - 1999. The biochemical ecology of marine fishes. In: A.J. Southward, P.A. Tayler, and C.M. Young (eds.), Advances in marine ecology, Vol 36. Academic Press. London.

Shulman, G.E., V.N. Nikolsky, T.V. Yuneva, G.S. Minyuk, V.Y. Shchepkin, M. Alla, A.M. Shchepkina, E.V. Ivleva, I.S. Dobrovolov, B. Ferit, B. and A.E. Kideys. - 2005. Fat content in Black Sea sprat as an indicator of fish food supply and ecosystem condition. Mar. Ecol. Prog. Ser., 293: 201-212

Smith, C.J., C.J. Papadopoulou and S. Diliberto. - 2000. Impact of otter trawling on an eastern Mediterranean commercial trawl fishing ground. ICES J. Mar. Sci., 57: 1340-1351.

Sogard, S.M. and B.L. Olla. - 2000. Endurance of simulated winter conditions by age- 0 walleye pollock: effects of body size, water temperature and energy stores. J. Fish Biol., 56: 1-21.

Somarakis, S., Ch. Stamataki, A. Machias, N. Papadopoulou, C. Smith and K. Karakassis. - 2004. Condition and fecundity of red mullet over muddy and "coralligene" substrata. Rapp. Comm. Int. Mer Médit., 37, pp. 443.

Templado, A. and C. Calvo. - 2002. Flora y fauna de la reserva marítima de las Islas Columbretes. Ministry of Agriculture, Food and Fisheries of Spain.

Tserpes, G., F. Fiorentino, D. Levi, A. Cau, M. Murenu, A. Zamboni and C. Papaconstantinou. - 2002. Distribution of Mullus barbatus and M. surmuletus (Osteichtyes: Perciformes) in the Mediterranean continental shelf: implications for management. Sci. Mar., 66S2: 39-54.

Tornaritis, M. E Peraki, M. Georgulli, A Kafatos, G. Charalambakis, P. Divanack, M. Kentouri, S. Yiannopoulos, H. Frenaritou and R. Argyrides. - 1993. Fatty acid composition and total fat content of eight species of Mediterranean fish. Int. J. Food Sci. Nutr., 45: 135-139.

Wanless, S., M.P. Harris, P. Redman and J.R. Speakman. - 2005. Low energy values of fish as a probable cause of a major seabird breeding failure in the North Sea. Mar. Ecol. Prog. Ser., 294: 1-8.

Yoshida, H.O. - 1980. Synopsis of biological data on bonitos of the genus Sarda. NOAA Tech. Rep. NMFS Circ. 432. FAO Fishery Synopsis No. $118.50 \mathrm{pp}$.

Scient. ed.: A. Sabatés.

Received December 15, 2006. Accepted February 20, 2007.

Published online May 21, 2007. 
